\title{
States, firms, and security: How private actors implement sanctions, lessons learned from the Netherlands
}

\author{
Francesco Giumelli ${ }^{1 *}$ (D) and Michal Onderco ${ }^{2}$ (D) \\ ${ }^{1}$ Department of International Relations and International Organization, University of Groningen, The Netherlands and \\ ${ }^{2}$ Department of Public Administration and Sociology, Erasmus University Rotterdam, The Netherlands \\ ${ }^{*}$ Corresponding author. Email: f.giumelli@rug.nl
}

(Received 9 April 2020; revised 19 November 2020; accepted 19 November 2020; first published online 7 January 2021)

\begin{abstract}
While the current practice of the United Nations Security Council, the European Union, and the United States leans towards imposing only targeted sanctions in most of the cases, private actors often complain about inability to process financial transactions, ship goods, or deliver services in countries where sanctions targets are located. The impact of sanctions often ends up being widespread and indiscriminate because sanctions are implemented by for-profit actors. This article investigates how for-profit actors relate to the imposition of sanctions, how they reflect them in their decisions, and how they interact with the public authorities. The findings of our research show that for-profit actors, with the possible exception of the largest multinationals, do not engage with public authorities before the imposition of sanctions. The behaviour of for-profit actors in the implementation phase is in line with the assumption of firms and business as profit-maximisers. Weighting the profits from business against the costs of (non-)compliance and make the decisions that in their view maximise their profit. Indeed, de-risking seems to be the most common approach by the companies due to the uncertainties produced by the multiple and overlapping sanctions regimes imposed by the United Nations, the European Union, and the United States.
\end{abstract}

Keywords: Sanctions; Non-state Actors; Security; Implementation; Private Authority

\section{Introduction}

Businesses and non-governmental organisations (NGOs) lament that working in countries under sanctions has become extremely problematic as processing financial transactions, shipping goods, or delivering services is often denied by private actors. Complaints have been raised for countries in diverse locations, from Syria to Sudan. However, the current practices of the United Nations Security Council (UNSC), the European Union (EU), and the United States (US) lean towards imposing only targeted sanctions in most of the cases. Targeted sanctions were designed in the late 1990s with the specific aim to minimise the impact of sanctions on civilians and, especially, on those organisations that intended to provide humanitarian support to the population in need. ${ }^{1}$ Yet, the impact of sanctions is often widespread and indiscriminate because sanctions are implemented by for-profit actors. ${ }^{2}$ These actors alter the decisions of public authorities through their intermediation. Private actors undertake a conservative approach in implementing sanctions

\footnotetext{
${ }^{1}$ Daniel W. Drezner, 'Sanctions sometimes smart: Targeted sanctions in theory and practice', International Studies Review, 13 (2011), pp. 96-108.

${ }^{2} \mathrm{We}$ understand for-profit actors as those whose main business is generating profit.

(c) The Author(s), 2021. Published by Cambridge University Press on behalf of the British International Studies Association. This is an Open Access article, distributed under the terms of the Creative Commons Attribution-NonCommercial-NoDerivatives licence (http://creativecommons.org/licenses/by-nc-nd/4.0/), which permits non-commercial re-use, distribution, and reproduction in any medium, provided the original work is unaltered and is properly cited. The written permission of Cambridge University Press must be obtained for commercial reuse or in order to create a derivative work.
} 
and, as such, they tend to over-comply with the regulations in order to minimise their own economic risks. ${ }^{3}$ The role of for-profit actors in the policymaking process has been widely explored in the literature, therefore it should not come as a surprise that non-state actors can play a decisive role in the implementation phase of sanctions. ${ }^{4}$ Yet, the case of targeted sanctions implementation by for-profit actors has not been systematically and comprehensively investigated. While scholarship has mapped the phenomenon of overcompliance, ${ }^{5}$ there is scarce understanding of how for-profit actors act under the conditions of sanctions. Our research addresses this gap.

This article investigates how for-profit actors react to the imposition of sanctions, how they reflect them in their decisions and how they interact with the public authorities. Specifically, we aim to understand how firms and businesses consider sanctions in their decision-making during the pre- and post-imposition phase of sanctions. By doing so, we look at how firm-level decisions influence the outcomes of sanctions policy. The findings of our research show that for-profit actors tend to play a more active role in the implementation and evaluation phase of the sanctions cycle rather than in the earlier phase of the policy process (for example, ahead of the imposition of sanctions). This finding has relevance that is twofold. First, although one could expect that certain for-profit actors could lobby in favour of the imposition of sanctions, in general terms, for-profit actors support open trade and, therefore, should lobby against the imposition of sanctions. However, our research shows that for-profit actors, with the possible exception of the largest multinationals, do not engage with public authorities before the imposition of sanctions. This finding in itself is puzzling and cannot be accounted for by the existing scholarship neither on sanctions nor on private actors. A potential explanation for this trend is that for-profit actors understand sanctions as decisions belonging to the realm of high politics and, as such, beyond their sphere of influence. The presumably separate nature of the security realm is what makes sanctions different from trade or environmental policies, where businesses are actively engaged in lobbying. ${ }^{6}$

Second, the behaviour of for-profit actors in the implementation phase is in line with the assumption that firms and business are profit-maximisers. Weighing the profits from business against the costs of (non-)compliance, firms make the decisions which in their view maximise their profits. Indeed, de-risking seems to be the most common approach by companies due to the uncertainties produced by the multiple and overlapping sanction regimes imposed sometimes by the UN, the EU and, especially, by the US.

This article presents exploratory research with the Netherlands as a single case study. The Dutch case is a typical case because it is a liberal democracy that engages with international trade and, as such, it allows for the development of a theory that can be subsequently tested on other cases. Sanctions compliance is a common issue for Dutch businesses; another study found that 2,747 Dutch companies were impacted by the sanctions on Russia (and Russian counter-sanctions) alone. ${ }^{7}$ However, more broadly, every company can potentially be impacted by the systemic impact of sanctions. Our analysis is the result of two focus groups with

\footnotetext{
${ }^{3}$ Arnold Aaron, 'The true costs of financial sanctions', Survival, 58:3 (2016), pp. 77-100.

${ }^{4}$ Peter Grabosky, 'Beyond responsive regulation: The expanding role of non-state actors in the regulatory process', Regulation \& Governance, 7:1 (2013), pp. 114-23; Tanja A. Börzel and Thomas Risse, 'Governance without a state: Can it work?', Regulation \& Governance, 4:2 (2010), pp. 113-34.

${ }^{5}$ Cameron Johnston, 'Sanctions against Russia: Evasion, Compensation and Overcompliance', EUISS Briefs (Paris: EU Institute for Security Studies, 2015), available at: \{http://www.files.ethz.ch/isn/191182/Brief_13_Russia_sanctions.pdf\} accessed 19 November 2020.

${ }^{6}$ Marcel Hanegraaff, 'Transnational advocacy over time: Business and NGO mobilization at UN climate summits', Global Environmental Politics, 15:1 (2015), pp. 83-104; Dirk De Bièvre et al., 'International institutions and interest mobilization: The WTO and lobbying in EU and US trade policy', Journal of World Trade, 50:2 (2016), pp. 289-312.

${ }^{7}$ Michal Onderco and Reinout van der Veer, 'No More Gouda in Moscow? Distributive Effects of Sanctions Imposition', paper prepared for the ECPR Joint Sessions of Workshops, Toulouse (2020).
} 
representatives from the government (the regulators), the private sector (the regulated), and academic experts that took place in June and December 2018, as well as interviews with Dutch companies carried out in the summer and the fall of 2019.

This article is divided into five sections. The first section reviews the literature on how private actors played a role in the provision of security as public good. The second section describes how private actors can affect the policy process before the imposition of sanctions and during their implementation. The third section focuses on the Dutch case and presents the results of the empirical research. The fourth part discusses the findings and it attempts to draw generalisations from the case study. Finally, the conclusion summarises the main argument and it points in the direction of new research that could be carried out in the future.

\section{Targeted sanctions and for-profit actors}

International sanctions refer to foreign policy decisions taken by sovereign actors, such as the UN Security Council or states, to deal with either threats or challenges. The imposition of sanctions can be done with the aim to pursue policy objectives, from changing the behaviour of states/targets to sending signals to third parties. In any event, international sanctions in this article are intended as political decisions to inflict a penalty for undesired behaviour on other actors.

For private actors, targeted sanctions create an additional level of regulation that is imposed on their activities from above. Even if the companies are not themselves the target of the sanctions, the imposition of sanctions on third parties creates obligations for for-profit actors. Sanctions are imposed by states - either unilaterally or through multilateral institutions - on other actors. Yet they are implemented by the private actors, who remain legally obliged to comply with them through domestic and international law.

The oldest types of international sanctions are the so-called 'comprehensive sanctions'. The decision of Athens to ban the city of Megara from trading with the members of the Delian League in the fourth century $\mathrm{BC}$ and the decision of the UN to impose an embargo on Iraq following the invasion of Kuwait in 1990 followed the logic that no trade exchange of any sort was supposed to occur with sanctioned territories. ${ }^{8}$ These sanctions were non-discriminatory in their impact. The pain-gain logic motivated this approach, so the economic impact on the civilian population was to trickle up towards the ruling elite that would have to acquiesce in order not to pay the price of sanctions. ${ }^{9}$ This logic had already been defined as 'naïve' in the 1960 s. $^{10}$ Soon after the end of the Cold War it became evident that rather than trickle up, the comprehensive sanctions created humanitarian suffering and were not effective. The approach, therefore, needed to be revised. ${ }^{11}$

In addition, thanks to a normative shift that established a principle of international individual responsibility, the Security Council led an international discussion that aimed to consider sanctions not only against states, but also against individuals and non-state companies, the so-called targeted sanctions. ${ }^{12}$

\footnotetext{
${ }^{8}$ George Tsebelis, 'Are sanctions effective? A game-theoretic analysis', Journal of Conflict Resolution, 34:1 (1990), pp. 3-28; David Cortright and George A. Lopez, The Sanctions Decade: Assessing UN Strategies in the 1990s (Boulder, CO: Lynne Rienner Publishers, 2000).

${ }^{9}$ Miroslav Nincic and Peter Wallensteen, Dilemmas of Economic Coercion: Sanctions in World Politics (New York: Praeger, 1983).

${ }^{10}$ Johan Galtung, 'On the effects of international economic sanctions: With examples from the case of Rhodesia', World Politics, 19:3 (1967), pp. 378-416.

${ }^{11}$ David Cortright and George A. Lopez, Economic Sanctions: Panacea or Peacebuilding in a Post-Cold War World? (Boulder, CO: Westview Press, 1995); David Cortright and George A. Lopez, Smart Sanctions: Targeting Economic Statecraft (Lanham, MD: Rowman \& Littlefield Publishers, 2002).

${ }^{12}$ Cortright and Lopez, Smart Sanctions; Thomas J. Biersteker, Sue E. Eckert, and Marcos Tourinho, Understanding United Nations Targeted Sanctions (Cambridge: Cambridge University Press, 2016).
} 
Targeted sanctions (also known as 'smart' sanctions) are designed to minimise the impact on innocent civilians and to maximise the impact on the individuals responsible for certain policies. Such impact can be created, for instance by focusing on specific individuals and/or specific trade/ transactions that are linked to individual benefits and/or are instrumental to the achievement of policy goals. This followed the logic of a micro-foundation approach, which focused on how a targeted subset of a society was affected by sanctions rather than by looking at the macro aspects of it, such as GDP fall, financial inflow trends, etc. ${ }^{13}$

The sanctions that are commonly imposed are financial restrictions, economic boycotts, travel bans, and arms embargoes. Financial restrictions refer to limiting the access and movement of financial assets from or to specific individuals, as well as limiting resources that have been earmarked for certain political objectives. Economic boycotts indicate the regulation of trade of certain goods, from natural resources such as oil to spare parts of critical infrastructure and equipment used for internal repression. Travel bans are, by definition, measures against individuals to prevent them from travelling and/or accessing specific territories. Finally, arms embargoes are the most typical form of sanctions that can either target entire territories with the objective of reducing the lethal weaponry in a conflict area, or be tailored for certain individuals, groups, and territories. ${ }^{14}$

While the market is highly regulated and the role of public authorities is more decisive when it comes to travel bans and arms embargoes, the implementation of financial restrictions and economic boycotts requires a more direct involvement of non-state actors, which includes pertinently non- and for-profit actors. ${ }^{15}$ This new course for sanctions requires more detailed and reliable knowledge on the economic structure of the society where entities are targeted and, often, this knowledge resides outside of the public sphere and in the realm of the private sector. This is not only about information, but it is also related to the institutional capacity to act swiftly and effectively when it comes to authorising financial transactions and exporting sensitive technologies to a country. First, it is private actors (often for-profit) that deal directly with targeted individuals and their associates, so they are the only ones who possess certain information and are able to make certain assessments. Second, the institutional capacity to implement sanctions at the micro level is weak in public authorities. For example, transportation companies that can make a preventive assessment on whether a shipment is suspicious and, therefore, can contribute more swiftly and, above all, preventively to the safety of our societies.

De facto, sanctions regulations delegate decision-making power to for-profit actors because the latter are required to assess the risk of specific transactions. ${ }^{16}$ A targeted economic boycott is implemented by for-profit actors by analysing their products, notifying suspicious utilisation, and refraining from transactions that could undermine the objective of sanctions. For instance, a financial restriction would require stopping money being sent to individuals targeted by sanctions and others indirectly related to them. However, the burden to seek information regarding people indirectly linked to targets is the grey area wherein financial operators need to navigate.

\footnotetext{
${ }^{13}$ Jonathan Kirshner, 'The microfoundations of economic sanctions', Security Studies, 6:3 (1997), pp. 32-65.

${ }^{14}$ Francesco Giumelli, Coercing, Constraining and Signalling: Explaining UN and EU Sanctions after the Cold War (Colchester: ECPR Press, 2011); Biersteker, Eckert, and Tourinho, Understanding United Nations Targeted Sanctions.

${ }^{15}$ Maria Bergstrom, Karin Svedberg Helgesson, and Ulrika Morth, 'A new role for for-profit actors? The case of antimoney laundering and risk management', Journal of Common Market Studies, 49:5 (2011), pp. 1043-64; Karin Svedberg Helgesson and Ulrika Morth, 'Involuntary public policy-making by for-profit professionals: European lawyers on anti-money laundering and terrorism financing', Journal of Common Market Studies, 54:5 (2016), pp. 1216-32; Karin Svedberg Helgesson and Ulrika Morth, 'Client privilege, compliance and the rule of law: Swedish lawyers and money laundering prevention', Crime, Law and Social Change, 69:2 (2018), pp. 227-48.

${ }^{16}$ Francesco Giumelli, 'The role of for-profit actors in implementing targeted sanctions: The case of the European Union', in Oldrich Bures and Helena Carrapico (eds), Security Privatization (Cham, Switzerland: Springer, 2018); Gregoire Mallard, Farzan Sabet, and Jin Sun, 'The humanitarian gap in the global sanctions regime', Global Governance, 26:1 (2020), pp. 121-53.
} 
The role of private actors in the provision of public goods has been at the centre of the debate since the 1970 s with the New Public Management (NPM) Theory ${ }^{17}$ and regulatory capitalism. ${ }^{18}$ Given rapidly changing societies, the level of competence required to administer public goods was more easily produced and (more readily available) by market forces rather than by public institutions. ${ }^{19}$ Since the 1970s, the state has shifted towards becoming a regulatory entity rather than a direct provider of public goods. ${ }^{20}$ The more flexible structure of private companies reduced the costs for the provision of services compared to what public institutions could have done. This has led to the privatisation of several functions normally controlled by public authorities, such as education, health care, and the like. ${ }^{21}$

More recently, this trend towards privatisation has also affected security, as demonstrated by the debate on Private, Military and Security Companies (PMSCs). ${ }^{22}$ Andreas Kruck suggested three models for understanding the proliferation of PMSCs. First, a functionalist model points at the complexity of managing security and at the cost-efficiency. Second, a political/instrumentalist model suggests that the proliferation of PMSCs is due largely to the reduction of political costs for governments. Finally, privatisation of security is caused by an ideationist model according to which security privatisation is based on an idea of how a state should be organised. ${ }^{23}$ The evolution of the security market, however, is also characterised by the unintended consequences of the reliance on private actors for the provision of security, such as the rising costs, the lack of accountability of policy outcomes, and the weakening of state institutions. ${ }^{24}$

Similarly, the inclusion of for-profit actors in the implementation of public policies has also raised old questions regarding the capacity of private actors to hijack the policy process in an effort to steer public decisions to their benefit. ${ }^{25}$ This is the reason why lobbying has been highly regulated in order to limit the influence of for-profit actors in the decision-making process. ${ }^{26}$ However, this public-private interaction has also been praised since, as written above, private actors can provide vital information to public authorities in the designing of effective regulation and in increasing the fidelity of the private sector when it comes to implementing those

\footnotetext{
${ }^{17}$ Christopher Pollitt and Geert Bouckaert, Public Management Reform: A Comparative Analysis - Into The Age of Austerity ( $4^{\text {th }}$ edn, Oxford, UK: Oxford University Press, 2017).

${ }^{18}$ Academic scholarship has long argued that the goals of regulatory capitalism - to make public goods delivery more effective and cheaper by private actors - have scarcely materialised. See John Braithwaite, Regulatory Capitalism: How It Works, Ideas for Making It Work Better (Cheltenham: Edward Elgar, 2008); Fabrizio Gilardi, Delegation in the Regulatory State: Independent Regulatory Agencies in Western Europe (Cheltenham: Edward Elgar, 2008).

${ }^{19}$ Johan P. Olsen, 'Administrative reform and theories of organization', in Colin Campbell and Guy B. Peters (ed.), Organizing Governance: Governing Organizations (Pittsburgh, PA: University of Pittsburgh Press, 1988); Jan-Erik Lane, New Public Management (London: Routledge, 2000).

${ }^{20}$ Giandomenico Majone, 'The rise of the regulatory state in Europe', West European Politics, 17:3 (1994), pp. 77-101.

${ }^{21}$ Jessica F. Green, 'Transnational delegation in global environmental governance: When do non-state actors govern?', Regulation \& Governance, 12:2 (2018), pp. 263-76; Terence C. Halliday, Josh Pacewicz, and Susan Block-Lieb, 'Who governs? Delegations and delegates in global trade lawmaking', Regulation \& Governance, 7:3 (2013), pp. 279-98.

${ }^{22}$ Deborah D. Avant, The Market for Force: The Consequences of Privatizing Security (Cambridge, UK and New York: Cambridge University Press, 2005).

${ }^{23}$ Andreas Kruck, 'Theorising the use of private military and security companies: A synthetic perspective', Journal of International Relations and Development, 17 (2014), pp. 112-41.

${ }^{24}$ Elke Krahmann, States, Citizens and the Privatization of Security (Cambridge, UK and New York: Cambridge University Press, 2010); Anna Leander, 'The paradoxical impunity of private military companies: Authority and the limits to legal accountability', Security Dialogue, 41:5 (2010), pp. 467-90; Rita Abrahamsen and Michael C. Williams, 'Security beyond the state: Global security assemblages in international politics', International Political Sociology, 3:1 (2009), pp. 1-17; Peter W. Singer, Corporate Warriors: The Rise of the Privatized Military Industry (Ithaca, NY: Cornell University Press, 2003); Lucia Zedner, 'Liquid security: Managing the market for crime control', Criminology and Criminal Justice, 63:3 (2006), pp. 267-88.

${ }^{25}$ Tamar Barkay, 'Regulation and voluntarism: A case study of governance in the making', Regulation \& Governance, 3:4 (2009), pp. 360-75.

${ }^{26}$ Ken Godwin, Erik Godwin, and Scott H. Ainsworth (eds), Lobbying and Policymaking: The Public Pursuit of Private Interests (Thousand Oaks, CA: CQ Press, 2013).
} 
regulations. Either way, this aspect confirms that for-profit actors can play a role either before or after public authorities make decisions, which is what distinguishes the designing and the implementation phases of sanctions. In the design phase, for-profit actors can interact with public authorities by providing insiders' information on how their own sectors work, and by issuing early warning signs of certain practices by individuals and/or entities. Security appears to be no exception in this regard. ${ }^{27}$ In the implementation phase, for-profit actors have to make risk assessments based on the regulation(s) and, therefore, they can exercise notable agency on when and to what extent they should adhere to sanctions guidelines provided by public regulators. Although it has been acknowledged extensively that for-profit actors play a decisive role in determining the outcome of sanctions, there is an alarming scarcity of empirical research that look at the periods both before the imposition of sanctions as well afterwards. This article intends to fill this gap. The next section introduces the regulatory framework of sanctions for for-profit actors with a focus on the Dutch case.

\section{The world of sanctions today}

When for-profit actors engage in international trade today, they know that there is a possibility to deal with sanctioned entities, individuals, and sectors. The already regulated international market can often be altered by decisions of the UN but sanctions can also be imposed by regional organisations and states to address security challenges. Thus, we refer to sanctions as legal instruments that can be used by international organisations and states to alter the rules of international markets to deal with violations of norms, foreign policy challenges, and the like.

The most notable actor is the UN Security Council. According to Chapter VII of the UN Charter, the Security Council can decide for the 'complete or partial interruption of economic relations' with a member state if it poses a threat to international peace and security (Art. 41). ${ }^{28}$ The decisions under Chapter VII of the Security Council are mandatory; therefore implementing measures should be undertaken by member states and for-profit actors should ensure they act in accordance to those decisions.

Article 52 of the UN Charter explicitly authorises regional organisations to deal with 'matters relating to the maintenance of international peace and security' if 'their activities are consistent with the Purposes and Principles of the United Nations' (Art. 52). The effects of this article have encouraged certain regional organisations to rely on sanctions, even though sanctions decisions have not always been explicitly inspired by the principles of the United Nations. For example, the African Union (AU) or Mercosur have imposed sanctions on its own members to react to coups d'état or human right concerns. ${ }^{29}$

The EU is certainly the most state-like regional arrangement and, although the practice of imposing sanctions outside of the mandate of the UN has been criticised, states can also independently resort to sanctions as long as they are not in violation of international trade agreements (for example, WTO regulations, etc.). As such, the EU has resorted to sanctions under its Common Foreign and Security Policy (CFSP) going beyond the mandate of the UN, such as in the cases of Iran and North Korea, and acting autonomously from the Security Council, such as in the cases of Russia and Myanmar. ${ }^{30}$ When for-profit actors work with the EU market,

\footnotetext{
${ }^{27}$ Helena Carrapico and Benjamin Farrand, 'Dialogue, partnership and empowerment for network and information security: The changing role of the private sector from objects of regulation to regulation shapers', Crime, Law and Social Change, 67 (2017), pp. 245-63.

${ }^{28}$ Biersteker, Eckert, and Tourinho, Understanding United Nations Targeted Sanctions.

${ }^{29}$ Andrea Charron and Clara Portela, 'The UN, regional sanctions and Africa', International Affairs, 91:6 (2015), pp. 1369-85; Anna van der Vleuten and Andrea Ribeiro Hoffmann, 'Explaining the enforcement of democracy by regional organizations: Comparing EU, Mercosur and SADC', Journal of Common Market Studies, 48:3 (2010), pp. 737-58.

${ }^{30}$ Mikael Eriksson, Targeting Peace: Understanding UN and EU Targeted Sanctions (Farnham, UK; Burlington, VT: Ashgate, 2011); Francesco Giumelli, The Success of Sanctions: Lessons Learned from the EU Experience (Farnham:
} 
they know that sanctions are disciplined by regulations that are binding in all member states, but enforcement and penalties for non-compliance are decided by the member states for actions undertaken in the EU and/or by EU based companies even if outside of EU territory. The enforcement of sanctions regulations across different EU member states is unequal - while some member states have established specialised agencies and built elaborate institutional frameworks, others have not afforded as much attention to it. ${ }^{31}$ As a recent paper argued, at least in some EU member states, the willingness to beef up domestic enforcement capabilities is related to the salience among the political elites. ${ }^{32}$

However, the lion's share of sanctions for for-profit actors relates to the role played by the United States. Thanks to the Office of Foreign Assets Control (OFAC), the US has come to play a global role in sanctions enforcement with any company operating outside of US territory. By extending its sovereign claims beyond its own borders to the entities and individuals voluntarily using US dollars for their transactions, US authorities have de facto forced a number of for-profit actors to implement US sanctions regulations upon threats of severe economic and financial consequences. ${ }^{33}$ The central position of the US banks and the US dollar in the global economy have enabled the US to enforce its laws beyond its national border through legislating for entities using US dollars. ${ }^{34}$ Several European based for-profit actors have already come to terms with this and settled claims from US authorities to the billions, such as the notorious case of BNP Paribas for US $\$ 8.9$ billion. $^{35}$ If for-profit actors were to resist the requests of US authorities, they would be cut off from the US market and their CEOs would face criminal prosecution in US courts. In other words, EU-based companies are likely to follow US laws before even looking at EU regulations. Thus, for-profit actors operating in international markets know that their transactions could be affected by sanctions imposed by the UN, regional organisations, the EU and individual states, especially by the US. This is no exception for Dutch companies as we discuss below.

\section{Methods}

This is an exploratory study with empirical evidence selected in the Netherlands. The Netherlands is a typical case for a liberal democracy with an open trade economy. According to Eurostat, Dutch exports equal $€ 613$ billion and this is second only to Germany in nominal value. This indicates that the Netherlands is an illustrative case that can be used to observe the behaviour and enhance our understanding of the role of for-profit actors in sanctions policymaking in liberal democracies with open trade economies.

The data collection for this research took place in two different phases. First, we organised two workshops with companies, regulators and academic experts in June and December 2018. The workshop in June was open to few participants and it provided the framework to shape the dialogue for the December meeting. The June workshop was attended by four academics, three

Ashgate, 2013); Clara Portela, European Union Sanctions and Foreign Policy: When and Why Do They Work? (Milton Park, Abingdon, Oxon and New York: Routledge, 2010); Francesco Giumelli, Fabian Hoffmann, Anna Książczaková, 'The when, what, where and why of European Union sanctions', European Security, published online (2020).

${ }^{31}$ Niklas Helwig, Juha Jokela, and Clara Portela (eds), Sharpening EU Sanctions Policy: Challenges and Responses in a Geopolitical Era (Helsinki: Finnish Institute of International Affairs, 2020).

${ }^{32}$ Radka Druláková and Pavel Přikryl, 'The implementation of sanctions imposed by the European Union: A comparison of the Czech and Slovak Republics' compliance', Central European Journal of International \& Security Studies, 10:1 (2016), pp. 134-60.

${ }^{33}$ Oldrich Bures and Helena Carrapico (eds), Security Privatization: How Non-Security-Related Private Businesses Shape Security Governance (Cham, Switzerland: Springer, 2018).

${ }^{34}$ William Kindred Winecoff, 'Structural power and the global financial crisis: A network analytical approach', Business and Politics, 17:3 (2015), pp. 495-525; Jacob J. Lew and Richard Nephew, 'The use and misuse of economic statecraft: How Washington is abusing its financial might', Foreign Affairs, 97:6 (December 2018), pp. 139-49.

${ }^{35}$ Francesco Giumelli and Giulia Levi, 'Sanzioni: Alle imprese Europee la multa arriva dagli usa', Lavoce.Info (2016), available at: \{http://www.lavoce.info/archives/41389/sanzioni-alle-imprese-europee-la-multa-arriva-dagli-usa/\} accessed 19 November 2020. 
members of civil society and two members from the government. The objective of the meeting was to have a preparatory discussion to identify the priority areas for public-private interactions and to identify the best way to analytically frame them. The December workshop, which aimed to better understand the role of private actors before and after the imposition of sanctions, had nineteen participants: five representatives from academia, four regulators and ten representatives from the private sector. The event was structured in three different sessions. The first session focused on the interaction between private actors before sanctions are imposed. The second one revolved around the challenges that private actors face why trying to implement sanctions. Finally, the third session of the workshop discussed ways to overcome the challenges for effective publicprivate governance. In these workshops, there were four universities present at the events. From the regulators' side, the Ministry of Foreign Affairs, the Ministry of Finance, and the Dutch Central Bank attended the event. From the private sector, we had representatives of banks, legal experts, non-governmental organisations, consultancy firms, and exporting firms. Participants were mostly from small- and medium-sized enterprises, but numerous actors (for example, legal experts and consultants) had significant experience working with businesses of all sizes from diverse segments of the economy. The two workshops took place under Chatham House rules, and therefore we refer to workshop participants only by numbers. The second phase of empirical work took place in 2019 when we interviewed representatives of almost two dozen companies (not all are cited in this article as many of them were interviewed on background or off the record). Again, we aimed specifically at creating a diverse mix of interviewees. Some of our interviewees were from major actors in the Dutch economic landscape, others were smaller businesses in crucial segments of the Dutch economy. The semi-structured interviews took place in the Netherlands in person, by phone, and via email and were conducted under the condition of anonymity; therefore, references were coded numerically.

These kinds of investigations carry an obvious, yet crucial, acknowledgement. We are aware that observable behaviours of companies and state authorities are limited and this is due to two factors. First, for-profit actors as well as institutional ones have vested interests in the matter of the investigation, therefore they can either withdraw information or present biased views of the problem. Although still possible and advisable, drawing inferences and generalisations from our findings need to be carefully weighed against potential, yet substantial, unknowns. Second, we have been able to speak only to actors who are somehow involved in sanctions compliance, even if involuntarily. We have not tried reaching out to companies that deliberately circumvent the sanctions. In the course of our interviews, we heard 'urban legends' of strategies used by unscrupulous actors to circumvent sanctions. We were not, however, interested in mapping the criminal practices - rather, we were interested in knowing how for-profit actors try to consider sanctions in their decisionmaking. While these stories underline that for-profit actors are concerned about their profits, our article is mainly interested in how they use legal ways in this process.

\section{The Dutch setting}

As any EU member, the Netherlands has delegated the authority to impose sanctions to the European Union. A few exceptions exist when it comes to imposing travel bans and arms embargoes because these areas remain under the purview of member states, but economic and financial restrictions cannot be taken outside of the common market framework. Therefore, the Netherlands implements all restrictive measures decided by the Council of Ministers and has added individuals connected to terrorism in the Netherlands. ${ }^{36}$

The Sanctions Act of 1977 provides the legal framework for the implementation of restrictive measures, whether they are UN- or EU-led, and the responsible institution is the Ministry of

\footnotetext{
${ }^{36}$ Government of the Netherlands, 'Sanctions' (2019), available at: \{https://www.government.nl/topics/international-peaceand-security/compliance-with-international-sanctions\} accessed 19 November 2020.
} 
Foreign Affairs. ${ }^{37}$ Following the sanctions act, other measures were undertaken, such as the Act on Financial Supervision and the General Guidance on the Anti-Money Laundering and Counter-Terrorist Financing Act (Wwft), but for the sake of brevity we will refer to these hereafter as the sanctions regulations. In certain occasions, the Parliament needs to adopt new legislation to implement sanctions, for instance in the case of arms embargoes, but existing instruments can be used in other cases, such as for travel bans. The monitoring, implementation, and enforcement tasks are distributed across several institutions. The Public Prosecutor's Office $(\mathrm{OM})$ has a specialised prosecutor (officier van justitie) specialised in sanctions violations, supported by a focused team at the Tax and Customs Administration (Belastingdienst). ${ }^{38}$ Financial restrictions fall under the competences of the Dutch Central Bank and the Authority for the Financial Markets (AFM). ${ }^{39}$ Economic boycotts are in the portfolio of the Customs and, specifically, it is the Central Service for Import and Export (CDIU) that is tasked with the authority to grant exemptions for export and import of sanctioned goods. Finally, the Human Environment and Transport Inspectorate (ILT) authorises the access to and/or the passage over Dutch territory for shipping and flights. ${ }^{40}$

Although financial and economic sanctions have been largely under the competences of the EU for their implications on the functioning of the Common Market, the Netherlands has also expressed its intention not to impose restrictive measures autonomously. The only exception is the terrorist list in compliance with Security Council Resolution 1373 adopted in the aftermath of the events on 09/11. The resolution lay out principles according to which member states should identify potential threats to peace and security originating from their own territory. In the European Union, the EU has prepared its own list, but the Netherlands has a different list and not all individuals on the Dutch list are also on the EU list.

The Netherlands has set penalties for sanctions violations. The law prescribes a fine of up to $€ 830,000$ for individuals and companies and up to six-year imprisonment for individuals. If the act qualifies as a serious offence, then the fine can be raised up to 10 per cent of the turnover of what was declared by the legal entity in the year before the offence. There are also administrative fees for financial institutions for not meeting the basic requirements for compliance. The standard fine is $€ 500,000$ and up to $€ 1$ million, which increases to $€ 2$ million for recidivists. If the value gained in the violation is higher, then the fee can be increased to $€ 4$ million. While violations at an administrative level could be settled without media attention, cases of enforcement started to appear in the media in the past years. For instance, in 2017 the Public Prosecutor imposed a fine of $€ 80,000$ on $U$-freight Nederland for shipping military materials to Russia ${ }^{41}$ and a fine of $€ 50,000$ on a Dutch transport company, U-Freight Holland B.V., for transporting prohibited products via the Netherlands. ${ }^{42}$ In 2018, the director and two employees of Euroturbine were sentenced to community service and the company had to pay a fine of $€ 500,000$ for illegal trade of

\footnotetext{
${ }^{37}$ Government of the Netherlands, 'Implementation of Sanctions in the Netherlands' (2019), available at: \{https://www. government.nl/topics/international-peace-and-security/compliance-with-international-sanctions/implementation-of-sanctions-in-the-netherlands\} accessed 19 November 2020.

${ }^{38}$ Annechien Daalderop, 'Straf-en bestuursrechtelijke aansprakelijkheid van poortwachters', Tijdschrift Voor Compliance, 19:1 (2019), pp. 45-51.

${ }^{39}$ De Nederlandsche Bank, 'Tackling Financial and Economic Crime: One of the Two Pillars of Our Supervision' (2019), available at: \{https://www.dnb.nl/en/supervision/financial-and-economic-crime/index.jsp\} accessed 19 November 2020.

${ }^{40}$ Rijksoverheid, 'Beleid Voor Internationale Sancties' (2019), available at: \{https://www.rijksoverheid.nl/onderwerpen/ internationale-sancties/beleid-voor-internationale-sancties\} accessed 19 November 2020.

${ }^{41}$ 'OM Wil 80.000 Euro Boete Voor Ontduiken Russische Sancties’, Nos.Nl (9 September 2017), available at: \{https://nos.nl/ artikel/2201926-om-wil-80-000-euro-boete-voor-ontduiken-russische-sancties.html\} accessed 19 November 2020.

${ }^{42}$ de Rechtspraak, 'Halve Ton Boete Voor Doorvoer Militaire Goederen Naar Rusland' (2017), available at: \{https://www. rechtspraak.nl/Organisatie-en-contact/Organisatie/Rechtbanken/Rechtbank-Amsterdam/Nieuws/Paginas/Halve-ton-boetevoor-doorvoer-militaire-goederen-naar-Rusland.aspx\} accessed 19 November 2020.
} 
dual-use goods to Iran. ${ }^{43}$ Other smaller fines were imposed, but the lion's share of media attention went to the 'Crimea Bridge' story, which included the investigation of seven Dutch companies and their directors for exporting materials used by Russia to connect the Crimean peninsula to Russia. $^{44}$

However, Dutch companies have also been under international pressure because of the attention that OFAC paid to its companies. The first 'fine' dates back to 2006 when US authorities complained to ABN Amro for deals with Iran, Libya, Sudan, and Cuba, which was closed with a settlement of US $\$ 500$ million. The same happened again in 2010, but for a much lower amount of US $\$ 40$ million. ING bank agreed to pay US \$619 million in 2012 for transactions with Cuba, Sudan, Libya, Iran, North Korea and Myanmar. Not only banks, but also exporters and other companies had to settle with OFAC. ${ }^{45}$ In 2010, Aviation Service International BV had to pay US \$750,000 and in 2014, CWT B.V. ${ }^{46}$ and Fokker Service ${ }^{47}$ settled with US \$6 and US \$21 million, respectively. In 2015, the French-Dutch company Schlumberger Oilfield Holdings paid a massive US \$231 million for trade operations with Iran and Cuba. In August 2019, the Dutch branch of the US owned company PACCAR was fined US \$1.7 million for violations of the Iran sanctions in 2014 and $2015 .^{48}$

This overview shows that Dutch for-profit actors have been exposed to legislation on export control and sanctions. The next two sections present the summaries of the findings, followed by a discussion and a conclusion.

\section{Activities of private companies Designing phase}

Despite the rather extensive legal framework and unique circumstances, participants in our workshops agreed that for private companies, sanctions appear to be imposed suddenly, and firms prepare very little in advance for sanctions on specific countries. However, large and internationalised companies are aware of the problem and have compliance programs in place that can be used in case of immediate need. Alternatively, contracts for international transactions contain a 'sanctions clause', which indicates that the fulfillment of the obligations indicated in the contract can be subjected to the imposition of unexpected trade restrictions by national and international authorities (Workshop 2). ${ }^{49}$

From the private actors' perspective, the decision to impose sanctions on specific individuals/ countries is a result of the sanctions decision policy process, which is firmly in the hands of states (Workshop 1, Workshop 2, Interview A). Public regulators treat sanctions matters as state security and, as such, they actively exclude private companies from the designing phase (Workshop 2). Some law firms sometimes approach their particularly exposed (for-profit) clients (as long as

\footnotetext{
${ }^{43}$ Jan Verloop, 'Lessons from the Euroturbine case: Global trends and enhanced due diligence essential to safeguard your business', ACSS - Association of Certified Sanctions Specialists blog (2019), available at: \{https://sanctionsassociation.org/lessons-from-the-euroturbine-case-global-trends-and-enhanced-due-diligence-essential-to-safeguard-your-business/\} accessed 19 November 2020.

${ }^{44}$ Bart Meijer, 'Dutch firms probed for alleged breaches of EU sanctions on Russia', Reuters.com (4 May 2018), available at: \{https://www.reuters.com/article/us-russia-netherlands-sanctions/dutch-firms-probed-for-alleged-breaches-of-eu-sanctionson-russia-idUSKBN1I5201\} accessed 19 November 2020.

${ }^{45}$ Department of the Treasury, 'Settlement Agreement', MUL-565595 $\$(2012)$, available at: \{https://www.treasury.gov/ resource-center/sanctions/CivPen/Documents/06122012_ing_agreement.pdf\} accessed 19 November 2020.

${ }^{46}$ Department of the Treasury, 'ENFORCEMENT INFORMATION FOR April 18, 2014', CFR $501.805 \$(2014)$, available at: $\{$ https://www.treasury.gov/resource-center/sanctions/CivPen/Documents/20140418_cwt.pdf $\}$ accessed 19 November 2020.

${ }^{47}$ Department of the Treasury, 'ENFORCEMENT INFORMATION FOR June 5, 2014' (2014), available at: \{https://www. treasury.gov/resource-center/sanctions/CivPen/Documents/20140605_fokker.pdf\} accessed 19 November 2020.

${ }^{48}$ Department of the Treasury, 'ENFORCEMENT INFORMATION FOR August 6, 2019' (2019), available at: \{https:// www.treasury.gov/resource-center/sanctions/CivPen/Documents/20190806_paccar.pdf\} accessed 19 November 2020.

${ }^{49}$ Please see list of Workshops and Interviews in the Appendix.
} 
these have appropriate agreements with the law firm) in advance, advising them to exercise caution in individual jurisdictions as a risk-mitigation measure (Workshop 2). While the participants from the law firms agreed that such activities might happen, participants also showed general difficulty with this approach. Many legal advisors find it difficult to give advice beyond a simple 'watch out' warning, which is not very helpful to companies (Workshop 2), given the uncertainties related to the outcome of the sanctions design process.

Based on the workshops and interviews, we also found that companies rarely lobby governments in relation to the imposition of sanctions. From both the workshops and the subsequent interviews, it appears that only particularly large entities have sufficient insight to consider potential future sanctions as well as the capacity to lobby governments at the time when sanctions are being negotiated. These large actors often adopt a long-term strategy of developing close contacts with regulators not only in the Netherlands, but also in other countries. These contacts are often the result of years (if not decades) of engagement in professional networks. Companies (and individuals) that develop such close contacts see them as increasing their resilience in case of sanctions imposition, and as absolutely essential for the success of their business (Interview E, Interview F). They are also able to develop closer relationships with external compliance consultants (or develop such expertise in-house), which allows them to also develop a comparative edge against their competitors. However, for the vast majority of firms, compliance starts to concern them only once the sanctions regime is imposed, as the participants in both our workshops outlined (Workshop 1, Workshop 2). Additionally, while the literature may suggest that companies are naturally over-complying, ${ }^{50}$ we noticed an intra-firm conflict between the compliance department and sales, since the former is often seen as a hindrance to profit and, as such, bad for business (Workshop 2).

Overall, we found that most companies (except for large multinationals, or companies used to operating in geopolitically complex environments) did not engage in lobbying, and also had very little awareness of the geopolitical surroundings in which they operate. This lack of awareness often leads them to ignore potential risks or find out about them too late. This finding corresponds with the findings of scholars who studied how firms look at political risk in general, which has underlined the continuous need for the companies to pay more attention to the political developments in the world that affect their businesses. ${ }^{51}$ While major geopolitical events, like wars, might attract the attention of firms, firms appear to be paradoxically more oblivious to lower levels of tension, such as imposition of sanctions - even if these can equally impact their business. ${ }^{52}$

\section{Implementation phase}

If the establishment of sanctions finds for-profit actors often unprepared, the implementation also poses challenges for these actors. Yet cooperation by for-profit actors is often seen as important by public authorities, because they know their clients often much better than public authorities.

In principle, we found that the companies faced two types of problems: (1) companies did not know who the targets of sanctions are, or are supposed to be, and that their goods might be subject to sanctions, but even if they did; (2) they did not know how much 'due diligence' they should do, a problem exacerbated by the reluctance of public authorities to engage in an earnest discussion.

\footnotetext{
${ }^{50}$ Oldrich Bures, 'Private actors in the fight against terrorist financing: Efficiency versus effectiveness', Studies in Conflict \& Terrorism, 35:10 (2012), pp. 712-32.

${ }^{51}$ Condoleeza Rice and Amy Zegart, Political Risk: How Businesses and Organizations Can Anticipate Global Insecurity (New York, NY: Twelve, 2018).

${ }^{52}$ One of the excellent EJIS reviewers suggested that the lack of lobbying might be also due to the concern about reputation. While it is undeniable that companies are concerned about their reputation (as we discuss later in the article), during our interviews the lack of awareness was clearly most prominently cited by our interviewees.
} 
Finding the targets: The participants in our workshops often talked about compliance with sanctions in connection to compliance with money-laundering regulations, terrorism financing, and corruption prevention. ${ }^{53}$ In a way, private actors did not see much difference between sanctions compliance and other forms of regulation imposed on them by public authorities. The situation is particularly difficult when it comes to smaller businesses, including start-ups, as they are often unaware that their products might be subject to sanctions or export controls. One of our interviewees highlighted that the company he worked for (small enterprise) had no idea about which goods were sanctioned (Interview B). This unawareness also reflects the low awareness about the extent of sanctions regimes, and about the complex interdependent relationship. One of our workshop participants gave an example of a machinery producer that could not understand why it would not be able to be paid for an item exported to Iran, even though that piece had no use in nuclear or missile programs (Workshop 2).

Once made aware of a sanctions regime that impacts their business, companies either set up a compliance program or they apply their existing ones to the new cases of sanctions (see above) (Workshop 2). The shape and scope of such program often depends on the size of the company and the frequency of interactions with potentially sanctioned entities.

In both interviews and workshops, it transpired that smaller companies tend to have a manual system, whereas larger firms (or banks) tend to have large, automated, systems based on software. Based on both the workshops and interviews, private actors who do not use consultants or compliance software lament frequent changes in sanctions lists and the fact that the lists on the websites of the EU and the UN are often not up to date (for example, they do not reflect the results of legal challenges to listings) (Workshop 1, Workshop 2, Interview A). This feeling was encapsulated by interviewee $B$, who complained that 'sanctions would be easy, if the politicians did not change the lists all the time'.

To an extent, these problems are often mitigated by automation and software. Modern software provides companies with detailed information, including the network models of connections between entities. Software providers organise events on sanctions compliance, in which they both seek to attract new clients and showcase the satisfaction of existing clients - see, for example, the event organised by Acuity. ${ }^{54}$ In another setting, Dutch observers also remarked that the compliance units of Dutch companies - including major banks, investment funds, and trusts - often face problems caused by the lack of expertise by their staff, which is caused by underinvestment in human capital. ${ }^{55}$

On their part, however, the private actors decry a similar lack of expertise on the part of the regulators. In particular, companies lamented that public authorities would not be able to promptly and specifically address their questions and needs (Interview E, Interview F). Firms explained this in two different ways. First, a lack of competence was certainly brought up; second, firms suggested that the institutional incentive for Dutch officials were such that they were discouraged to take risks and, therefore, the guidelines are often either restrictive or conservative.

\footnotetext{
${ }^{53}$ Sanctions consultants also offer services in one package together with export controls. See, for example, the sheets developed by FTI Consulting. FTI Consulting, 'Anti-Money Laundering, Sanctions \& Anticorruption Solutions' (FTI Consulting, 2017), available at: \{https://www.fticonsulting.com/ /media/Files/us-files/insights/brochure/anti-money-laundering-sanctions-corruption-solutions.pdf\} accessed 19 November 2020, or FENEX Training Fenex, 'Export Control, Dual-Use En Sancties Hoofddorp' (Fenex. De Nederlandse organisatie voor expeditie en logistiek, 2020), available at: \{https://www. fenex.nl/export-control-dual-use-en-sancties-hoofddorp\} accessed 19 November 2020.

${ }^{54}$ Accuity, 'Sanctions Complexity: How to Combat with AI Techniques and Predictive Analysis' (2019), available at: \{https://accuity.com/event/sanctions-complexity-how-to-combat-with-ai-techniques-and-predictive-analysis/\} accessed 19 November 2020.

${ }^{55}$ Geert Vermeulen, 'Banken Als Poortwachters van Het Financiële Stelsel: Werkt Dat Een Beetje?', Tijdschrift Voor Compliance, 19:1 (2019), pp. 24-31.
} 
Due diligence and communication with the authorities: The costs of software solutions are, based on the information gleaned in our workshops, manageable. However, doing business in some jurisdictions where tracing goods and transactions is complex creates problems for actors in two ways: firstly, because there is a grey zone in which rules are unclear; and secondly because even if the rules are clear, it is not easy to ensure their implementation with 100 per cent certainty.

The first problem arises because the public authorities delegate risk assessment to the private companies. While in an ideal world, the for-profit actors could ask authorities about guidance in particular cases, companies are reluctant to do so. The public authorities are seen as too conservative, and prefer to err on the side of the caution. At the same time, the companies are hesitant to reveal their identities in order not to reveal possible non-compliance. While the US authorities are willing to answer questions on the 'no name basis' (meaning that only a very general query is submitted to OFAC through a counsel, without naming the company in question), the situation is more complicated when it comes to the national and European regulations (and regulators) (Workshop 2). However, there are consulting companies that offer the opportunities of mediating between companies and authorities. ${ }^{56}$ In August 2019, the European Commission published a non-binding guideline on internal compliance programs, ${ }^{57}$ but private actors in our interviews still highlighted what they saw as an uncertain situation (Interview E, Interview F). Based on our interviews, it appears that many businesses find guidance from compliance consultants, but also sector organisations and lobbies, which supply information to their members. The cooperation with the public sector does not necessarily benefit the private sector only: in an unrelated setting of terrorism financing regulation, a simple pilot of exchange of information between banks and public prosecutor led to three hundred 'hits'. ${ }^{58}$

The second problem arises from complicated supply chains for numerous products, as well as from unclear arrangements in foreign jurisdictions. Numerous smaller actors working in sensitive environments (particularly countries with large/institutionalised terrorist structures) are having a hard time identifying sanctioned actors. To quote one of the participants in our December 2018 workshop, 'if you sell to a company in Latin America, how can you know it is not a Hezbollah front?' (Workshop 2).

In the face of such uncertainty, companies choose from one of the three solutions: they either shift the burden contractually, spend even more money on compliance by using boutique consulting services and comprehensive data and software (see, for example, Accuity's software offer), ${ }^{59}$ or de-risk by withdrawing.

The first strategy used by companies to mitigate the risk (or to avoid their goods ending up in a sanctioned country) is to contractually shift the responsibility for compliance to intermediaries. Participants agreed that intermediaries who refuse to accept such a responsibility are a 'red light', however, exporters often do not even know where some of their items end up, because they can pass through a number of jurisdictions before ending up in a sanctioned country. However, participants in workshops as well as interviewees highlighted that authorities nevertheless often try to act against the intermediaries. Private companies see this as unfair and a result of the impossibility to act against the sanctions violators in third countries, especially in countries with

\footnotetext{
${ }^{56}$ FTI Consulting, 'Anti-Money Laundering, Sanctions \& Anticorruption Solutions'.

${ }^{57}$ European Union, 'Commission Recommendation (EU) 2019/1318 of 30 July 2019 on Internal Compliance Programmes for Dual-Use Trade Controls under Council Regulation (EC) No 428/2009' (Brussels: European Commission, 2019), available at: $\{$ https://eur-lex.europa.eu/legal-content/EN/TXT/?uri=CELEX\%3A32019H1318\} accessed 19 November 2020.

${ }^{58}$ Dennis Mijnheer, 'Publiek-private samenwerkingen bij de bestrijding terrorismefinanciering', Tijdschrift Voor Compliance, 19:1 (2019), pp. 5-11.

${ }^{59}$ Accuity, 'Sanctions, PEP, and Screening Data' (2019), available at: $\{$ https://accuity.com/what-we-do/sanctions-screeningpep-data/?intcmp=full-footer-what-we-do-sanctions-screening-pep-data\} accessed 19 November 2020; Accuity, 'Firco Online Compliance: The Comprehensive Online Solution that Delivers KYC Screening Results You Can Rely On' (2019), available at: \{https://accuity.com/product/online-compliance/?intcmp=summary-product-online-compliance\} accessed 19 November 2020; FTI Consulting, 'Anti-Money Laundering, Sanctions \& Anticorruption Solutions'.
} 
problems with law enforcement. At the same time, the companies see this as a disadvantage, compared to their competitors in other countries (this view was expressed to us by a number of companies, but also some officials), as authorities in other countries are often more relaxed with sanctions enforcement.

The second strategy that companies use to ensure compliance is by resorting to the boutique, specialist consultants, and some of the largest companies are even able to send their own employees to the destination countries to ensure compliance. Consultants are also available not only to provide advice, but also to train staff in compliance-related matters. ${ }^{60}$

Some branch organisations, such as Fenex for the transport and logistics industry, offer workshops, training, and advice to the members of the branch organisations (Interview F) ${ }^{61}$ Especially our interviewees from the agricultural business highlighted the role of branch organisations as their point of contact and a source of expertise (Interview C and D). But this option is unavailable to smaller companies, as revealed during our workshops and in the interviews (Workshop 2, Interview A), and they often end up directly choosing for withdrawal by abandoning a particular partner or even a country. This specialised knowledge then becomes a competitive advantage for the larger companies, since they can provide better services to customers compared to smaller companies with less expertise, knowledge, and professional networks (Interview E and F).

The third strategy is de-risking by withdrawal in line with the findings from other research. ${ }^{62}$ Withdrawal is a strategy used by companies when the cost of compliance is too high compared to the potential profit, or if the cost of compliance is too high for the size of the firm. It is important to note that the cost of compliance includes not only the legal costs, but also potential reputational damage resulting from carrying out perfectly legal deals done in countries that had been criticised for dubious practices. As one of the participants put it, 'there's zero risk appetite' among the private companies. ${ }^{63}$ The likelihood of de-risking is therefore proportional to the risk related to a particular jurisdiction and to the size of the company. One of our interviewees told us about a Dutch cargo company that withdrew completely from a fairly lucrative market because while they were unable to ascertain which goods should not be transported to the given jurisdiction, they could not get a guarantee from the regulators that their program would be compliant (Interview E). Another interviewee mentioned that a bank stopped providing his company with services for the business in a country where EU targeted sanctions are in place, which the interviewee attributed to the small size of the interviewee's company (Interview B).

De-risking by for-profit actors might have consequences for other actors too, as it makes it often impossible to conduct even legitimate business in such countries. For example, difficulties exist in supplying humanitarian goods, even though these are not on any of the export control or sanctions lists. Banks are highly reluctant to authorise transactions to problematic jurisdictions. While for private companies, this is an economic problem, for humanitarian organisations and NGOs this poses a much more fundamental threat. Humanitarian organisations often feel that overcompliance is unconscionable (because it would mean denying aid to those who need it most), but they lack the resources for proper compliance (and often do not understand how someone would want to hinder them in the first place). Compliance also sometimes goes against

\footnotetext{
${ }^{60}$ Accuity, 'Firco Online Compliance'; FTI Consulting, 'Anti-Money Laundering, Sanctions \& Anticorruption Solutions'.

${ }^{61}$ Fenex, 'Control, Dual-Use En Sancties Hoofddorp'.

${ }^{62}$ Justine Walker, 'Humanitarian Impact of Syria-Related Unilateral Restrictive Measures', National Agenda for the Future of Syria (United Nations (UN) Economic \& Social Commission for Western Asia (ESCWA) (2016), available at: \{http://www. antikrieg.eu/aktuell/un_study_syria.pdf\} accessed 19 November 2020; Bures and Carrapico, Security Privatization; Biersteker, Eckert, and Tourinho, Understanding United Nations Targeted Sanctions; Larissa van den Herik (ed.), Research Handbook on UN Sanctions and International Law (Cheltenham, UK: Edward Elgar Publishing, 2017).

${ }^{63}$ What might further exacerbate the risk perception among the companies is that violation of sanction violations are characterised as criminal felonies and hence more heavily punished. See Annechien Daalderop, 'Straf- En Bestuursrechtelijke Aansprakelijkheid van Poortwachters', Tijdschrift Voor Compliance, 19:1 (2019), pp. 45-51.
} 
the spirit of their action (for example, they are reluctant to share the list of beneficiaries in order to protect their field staff).

The elephant in the room is, however, the role of US authorities in enforcing US regulations on all for-profit actors. Dutch actors are very exposed to either the use of US dollars or to financial institutions that use dollars on a regular basis. This means, in practice, that Dutch companies could incur financial consequences even if they themselves do not use US dollars to carry out any transactions because it would be financial institutions working with them that would act in compliance with US laws. While for-profit firms talk to Dutch and EU authorities whenever necessary, the real concern comes from the oversight exercised by the Office of Foreign Assets Control.

\section{Discussion}

The central contribution of this research is to directly engage with the role of private actors in the implementation of international sanctions. The study on the implementation of sanctions by Dutch firms enables us to contribute to a number of debates that are relevant to international relations, not only those highlighted above - that is, the reasons that explain why states rely on non-state actors to deliver public goods and the agency of non-state actors in public policy decision-making - but also at large, such as the nature of the international system and the concept of security.

We highlighted above the three reasons - functionalist, political/instrumentalist, and ideationist - for which states rely on private actors for the provision of public goods. Certainly our research provides confirmation for the functionalist hypotheses. Indeed, state authorities would be fine in carrying out the function by themselves, but have neither the resources nor the knowledge to do so. Therefore, the reliance on non-state actors is driven by the need to enhance the provision of security as a public good rather than the desire to shift political responsibility (political/instrumentalist) or by a specific idea of how a state should function (ideationist). This latter hypothesis can be understood, at best, as a permissive condition rather than a cause.

This premise opens the other theme we had identified above, namely the agency that non-state actors have in affecting the outcome of decisions made by public authorities. In general, our analysis suggests that non-state actors have a rather wide degree of agency, but there is a high degree of divergence on how they make use of it and we have looked at their role in the different phases of the policy cycle to explore it. One of the most common assumptions in studying non-state actors is that firms and companies are motivated by the sole intent to make profit. With the exception of the literature on Corporate Social Responsibility (CSR), which holds that for-profit actors can also embark on non-profit making activities, ${ }^{64}$ it is expected that for-profit actors are inclined to maximise profits under any circumstances. Consequently, for-profit actors would engage with public authorities whenever it would contribute to the maximisation of their profits. ${ }^{65}$

Contrary to our expectations, we found the private actors, by-and-large, absent from the designing phase of sanctions, before the sanctions are implemented. While it is possible that there are a few exceptions (especially in the case of particularly large actors), these were very few. Given that the imposition of sanctions creates costs for private companies, we find the absence of private actors from the policy process prior to the imposition of sanctions surprising.

From the utility maximising perspective, there are three possible explanations for this. First, there is a collective action problem as companies would wait for others to lobby against sanctions,

\footnotetext{
${ }^{64}$ Daniel Vogel, 'The private regulation of global corporate conduct: Achievements and limitations', Business \& Society, 49:1 (2010), pp. 68-87; Archie B. Carrol, 'Corporate social responsibility: Evolution of a definitional construct', Business \& Society, 38:3 (2019), pp. 268-95.

${ }^{65}$ Jonathan Kirshner, Appeasing Bankers: Financial Caution on the Road to War (Princeton, NJ: Princeton University Press, 2007); Kevin Narizny, The Political Economy of Grand Strategy (Ithaca, NY: Cornell University Press, 2007); Patryck J. McDonald, The Invisible Hand of Peace: Capitalism, the War Machine, and International Relations Theory (New York, NY: Cambridge University Press, 2009).
} 
so they could trade without paying the costs of lobbying. This would also explain the rising role for branch organisations in sanctions, compliance, and export control. Second, there are reputational concerns in lobbying against sanctions that could be imposed for national security concerns, such as the protection of borders, or normative values, such as human right violations. Third, there are differences across companies, so while some would lose by imposing sanctions, others might gain versus their competitors. This would explain why some companies would not lobby against sanctions as some would certainly gain out with a closer economy. From a normative angle, a fourth explanation would suggest that companies do not lobby because they follow a logic of appropriateness and, therefore, they accept the value judgement made by state authorities. Indeed, almost every interlocutor we spoke to highlighted that they saw sanctions as 'political', which we interpret as meaning 'negotiated above our paygrade'. For these for-profit actors, the worlds of politics and business appear to be separated, and sanctions clearly in the realm of politics, which would explain why companies do not lobby. The exception confirming the rule in this case would be the one of large for-profit actors who did become involved in the pre-imposition phase thanks to the close relationship they have with the regulators. On the one hand, this close relationship allowed them to develop a competitive edge over their competitors, but on the other, this close relationship is justified by the fact that large for-profit actors often share their fate with the regulators and, as such, they are already providers of public goods.

This finding also provides further empirical confirmation for the Corporate Security Responsibility (CSR) concept. ${ }^{6}$ Accordingly, a strict separation of roles between states dealing with security matters and for-profit actors dealing with low politics is unable to capture the role that certain firms have been fulfilling also in high politics matters. ${ }^{67}$ In fact, companies have gradually acquired crucial functions in the provision of security, such as in the case of PMSCs and in the protection of critical infrastructure. Coherently, this research brings further empirical evidence to the fact that firms and for-profit actors are increasingly, although often unwillingly, acquiring a central role in the state-led provision of security. Firms and, more in general, while pursuing private gains, for-profit actors are also key players in assessing risks and determining the outcome of security processes when implementing sanctions regulations.

Pareto optimal equilibria are rare events in public policy analysis, ${ }^{68}$ therefore the implementation of sanctions regulations create different incentives for companies. For instance, the vast scholarship work on disaster capitalism confirms that even the most dreadful events can create profit opportunities for certain actors, regardless of their profit or non-profit nature. ${ }^{69}$ Indeed, our research has demonstrated that there is a sharp divide between large companies and smaller, niche companies. While the former can afford specialised consultants, software, and often extensive in-house expertise, most of the smaller companies are often either left to their own devices or rely on the advice by sector organisations and lobbies. Importantly, however, we see little lobbying by these interest groups for repealing sanctions, similar to the finding of David Lowery ${ }^{70}$ who found that interest organisations might forego lobbying in order to attract members. These smaller enterprises often end up being the ones who find out about the applicability of sanctions to

\footnotetext{
${ }^{66}$ Klaus Dieter Wolf, Nicole Deitelhoff, and Stefan Engert, 'Corporate security responsibility: Towards a conceptual framework for a comparative research agenda', Cooperation and Conflict, 42:3 (2007), pp. 294-320; Nicole Deitelhoff and Klaus Dieter Wolf (eds), Corporate Security Responsibility? Corporate Governance Contributions to Peace and Security in Zones of Conflict (Basingstoke and New York: Palgrave Macmillan, 2010).

${ }^{67}$ Oldrich Bures, 'Political corporate social responsibility: Including high politics?', Journal of Business Ethics, 129 (2015), pp. 689-703.

${ }^{68}$ Charles Cohen and Erid D. Werker, 'The political economy of "natural" disasters', Journal of Conflict Resolution, 52:6 (2008), pp. 795-819.

${ }^{69}$ Antony Loewenstein, Disaster Capitalism: Making a Killing out of Catastrophe (London and New York: Verso Books, 2015); John C. Mutter, The Disaster Profiteers: How Natural Disasters Make the Rich Richer and the Poor Even Poorer (New York: St Martin's Press, 2015).

${ }^{70}$ David Lowery, 'Why do organized interests lobby? A multi-goal, multi-context theory of lobbying', Polity, 39:1 (2007), pp. 29-54.
} 
their businesses at the moment when it is too late - when they are already involved in a problem or a dispute.

This holds true when it comes to implementing public regulations that can imply economic losses and are exposed to free riding behaviour. On the one hand, there are companies that decided to collaborate with public authorities in the provision of public goods and, on the other, there are those who decide to violate sanctions often driven by a profit-maximising strategy. Rather than being an emergence of private actors, we witness the split among for-profit actors between those who want to participate in the provision of public goods and those who do not want to. There are several companies that try hard to comply with public regulations and opt for de-risking in order not to incur violations. But the regulation of trade also creates higher returns, therefore there are companies that could take advantage of the situation by not asking public authorities any previous authorisation. It can be assumed that companies belonging to the former type are more likely to be willing to be interviewed, while the latter may have reservations, this is why our empirical sample is to be considered bias in nature. In sum, we argue that there is an emerging system of opposing alliances with states and some for-profit actors on one end, and the others on the other end of the continuum.

Our study provides insight into the evolving nature of the state in the international system. For instance, it offers evidence for those who hold that the growing complexity and interdependence of the international system have weakened the role of states, ${ }^{71}$ which therefore need to extend their regulatory influence over companies in order to extract information from them that public authorities do not otherwise possess. ${ }^{72}$ Indeed, states would not be able to effectively design and impose sanctions without the necessary information provided by for-profit actors, such as banks and shipping companies. ${ }^{73}$

At the same time, the extension of the public reach over private actors can also speak to those who claim that the state is coming back to its centrality in the international system. This phenomenon has also been depicted as the expansion of the public realm. ${ }^{74}$ Indeed, the dominant narrative of globalisation is that the market would be the main instrument to allocate resources across space. However, when it comes to sanctions, we see that certain states remain more influential than others. ${ }^{75}$ For instance, the centrality of the US dollar in international markets grants the US administration a higher degree of influence and pervasiveness that is unmatched by any other state in the international system. The efforts to counterbalance the US influence by the European Union, among others, have been brushed aside by Dutch companies' representatives as futile, which confirms that the market is yet heavily influenced by the role played by the 'benevolent hegemon'. In a way, our study provides an empirical confirmation for international institutions to reflect a specific distribution of power among states.

Our article also speaks to the literature on the broadening of the concept of security. ${ }^{76}$ While security traditionally refers to physical and direct threats to states, this research on the role of for-

\footnotetext{
${ }^{71}$ Martin Shaw, 'The state of globalization: Towards a theory of state transformation', Review of International Political Economy, 4:3 (1997), pp. 497-513; Elemer Hankiss, 'Globalization and the end of the nation state?', World Futures, 53:2 (1999), pp. 135-47.

${ }^{72}$ Jacqueline Best and Alexandra Gheciu, The Return of the Public in Global Governance (Cambridge: Cambridge University Press, 2014).

${ }^{73}$ Tim Büthe and Walter Mattli (eds), The New Global Rulers: The Privatization of Regulation in the World Economy (Princeton, NJ: Princeton University Press, 2011); Gary Teeple and Stephen McBride (eds), Relations of Global Power: Neoliberal Order and Disorder (Toronto, ON: University of Toronto Press, 2011).

${ }^{74}$ Best and Gheciu, The Return of the Public in Global Governance.

${ }^{75}$ Clyde W. Barrow, 'The return of the state: Globalization, state theory, and the new imperialism', New Political Science, 27:2 (2005), pp. 123-45.

${ }^{76}$ Michael C. Williams, 'Words, images, enemies: Securitization and international politics', International Studies Quarterly, 47:4 (2003), pp. 511-31; Thierry Balzacq (ed.), Securitization Theory: How Security Problems Emerge and Dissolve (Abingdon and New York, NY: Routledge, 2010); Barry Buzan, Ole Wæver, and Jaap de Wilde, Security: A New Framework for Analysis
} 
profit actor in implementing sanctions suggests that any financial transaction or any trade agreement between any actors could constitute a security threat. In other words, if any transaction can constitute a violation of sanctions, even when indirectly related to them, then any transaction is a potential security threat. This means that the governance of security should be concerned with protecting a state from foreign invasions as well as 'everything else'. This understanding of security resembles the debate on critical infrastructures where the collapse of a given infrastructure given it communications, banking, gasoline distribution and electricity provision, just to mention some - would have direct implications for the lifestyle of modern societies. ${ }^{77}$

Daniel Drezner's 2011 paper on targeted sanctions is titled 'Sanctions Sometimes Smart'. Our work on the implementation of sanctions by for-profit actors demonstrates that Drezner's article's title was prophetic. Our research therefore confirms that even if modern sanctions should, in theory, be 'tailored', they often end up comprehensive in practice. This is because the private actors, who are left to implement them, often find the rules too byzantine to interpret and enforce, and therefore choose de-risking over facing potential fines. Both in interviews and in the workshops we conducted, it became clear that for-profit actors considered the impositions of sanctions as unpredictable and their enforcement somewhat arbitrary. While a thorough discussion would fall outside the scope of this analysis, we argue that the central role of non-state actors in the designing and implementation of sanctions can have very direct and important implications on how we think and assess the effectiveness of sanctions.

\section{Conclusions}

For-profit actors became crucial to explain the impact of targeted sanctions. Decisions made by firms and companies may alter the intention of the decisions made by public authorities. The role of for-profit actors, therefore, determines the outcome of public policy processes. While the literature limited its attention to the ways in which this occurs in the implementation of a public regulation, we broadened the scope of the question and investigated how for-profit actors behave before the imposition of sanctions with the aim to enhance the understanding of how they can influence the decision of resorting to sanctions.

The empirical analysis carried out in 2018 and 2019 with Dutch companies led us to two main findings. First, for-profit actors rarely lobby in favour of and/or against sanctions, which is considered a 'high' politics issue in the portfolio of states. Occasionally, only larger corporations have the resources and time to lobby about sanctions, but the general approach of firms is to be reactive rather than proactive in the sanctions realm. Second, the imposition of sanctions is seen as highly problematic for companies, which are more likely to disengage from risks of sanctions violations than investing resources on building up due diligence procedures that would be needed for the temporary existence of sanctions. In other words, de-risking is the main strategy for companies and this finding is coherent with the wider literature on the subject.

These findings from the empirical analysis of the Dutch case provide important contribution to ongoing debates in International Relations scholarship. Most directly, the case study contributes to the study of sanctions and their implementation by looking at firm-level interpretation, hitherto an overlooked aspect. However, it is also more broadly relevant beyond the study of sanctions. It particularly speaks to the literature on public-private relationships on how and under

(Boulder, CO: Lynne Rienner Publishers, 1998); Jef Huysman, 'Security! What do you mean?: From concept to thick signifier', European Journal of International Relations, 4:2 (1998), pp. 226-55.

${ }^{77}$ Eric Vugrin, Drake Warren, and Betty Biringer, Critical Infrastructure System Security and Resiliency (Boca Raton, London, and New York: CRC Press, 2013); Matthew Jude Egan, 'Anticipating future vulnerability: Defining characteristics of increasingly critical infrastructure-like systems', Journal of Contingencies and Crisis Management, 15:1 (2007), pp. 4-17; Elsa Lee, Homeland Security and Private Sector Business: Corporations' Role in Critical Infrastructure Protection (New York: CRC Press, 2009). 
what conditions state authorities involve private actors in the provision of public goods. The literature is also relevant for the study of how the private sector engages the public sector.

Certainly, the generalisability of this study is limited. The empirical evidence is, by nature, biased by the fact that non-compliant firms/companies as well as behind-closed-door lobbying activities will not be reported. We are well aware that certain empirical evidence is not to appear in interviews. However, this study opened avenues for new research on the role of private actors and sanctions.

First, it emphasised that for-profit actors can lobby for high politics as well and that this should be further investigated. While there has been attention to lobbying in areas normally defined as low politics, high politics such as war and sanctions certainly deserve more attention. At the same time, future research should consider why so many businesses and companies consider sanctions policy to be beyond their reach, and do not engage in lobbying in this field.

Secondly, while our article has looked into differences between smaller and larger firms, due to the exploratory nature of the research we were not able to analyse other potential sources of variation in depth. Future studies should look into other possible sources of variation, such as the field or nature of firms. It is not unreasonable to expect that firms in different fields behave differently under sanctions. Researchers might unpack this relationship more systematically.

Second, the engagement with companies and public regulators contributed to generate a platform for discussion on shared problems. This approach has been used in other fields, but it represents an innovation in the study of sanctions and, more broadly, on the study of how private and public actors interact. Further explorations beyond the Dutch case would serve the purpose of comparing how different systems may be characterised by different practices.

Finally, further studies are absolutely necessary on the implementation of sanctions by forprofit actors across the European Union. The uneven implementation across the EU was raised several times during the workshop and the interviews, which highlights that divergent systems could exist in the 28 member states. This study was only the first of many relevant contributions that could enhance our understanding of sanctions and their implementation and our understanding of the role of for-profit actors in the provision of security as a public good.

Acknowledgements. The authors thank the participants in the workshops and the interviewees for sharing their insights and experiences. We would like to thank Eugenio Cusumano and Lukas Linsi as well as the editor and the three reviewers for their feedback. All remaining errors are our own. Deborah Bakker provided invaluable research assistance. Madeline Zutt proofread the manuscript with much care. The Independent Social Research Foundation generously funded the research underpinning this article. Michal Onderco thankfully acknowledges support from the Charles University Research Centre program UNCE/ HUM/028 (Peace Research Center Prague/Faculty of Social Sciences).

Francesco Giumelli is Associate Professor of International Relations and International Organization at the University of Groningen (The Netherlands). His research focus on international security and international political economy, with particular focus on targeted sanctions and illicit trade.

Michal Onderco is Associate Professor of International Relations at Erasmus University Rotterdam (The Netherlands). His research focuses on international security, with particular focus on domestic aspects of foreign policy and on nuclear proliferation.

\section{Appendix}

\section{List of interviews and workshops}

Workshop 1: 'Private Actors and Sanctions', organised at Erasmus University Rotterdam in June 2018 (organised under Chatham House rules).

Workshop 2: 'Private Actors and Sanctions' organised at Erasmus University Rotterdam in December 2018 (organised under Chatham House rules).

Interview A: Interview with a representative of a small company, July 2019.

Interview B: Interview with a representative of a small engineering company, July 2019.

Interview C: Interview with a representative of an agricultural business, August 2019. 
Interview D: Interview with a representative of an agricultural business, August 2019.

Interview E: Interview with a representative of a large enterprise, October 2019.

Interview F: Interview with a representative of a large enterprise, October 2019.

Interview G: Interview with a representative of a branch organisation, October 2019.

Cite this article: Giumelli, F., Onderco, M. 2021. States, firms, and security: How private actors implement sanctions, lessons learned from the Netherlands. European Journal of International Security 6, 190-209. https://doi.org/10.1017/eis.2020.21 